\title{
STUDENT TEACHERS' PERCEPTION OF THEIR TEACHING COMPETENCY ASSESSED BY A FRAMEWORK FOR ASSESSING STUDENT TEACHERS' ENGLISH TEACHING COMPETENCY (FASTETC)
}

\author{
Tran Quoc Thao* \\ Ho Chi Minh City University of Technology (HUTECH), \\ 475A Dien Bien Phu Street, Ward 25, Binh Thanh District, HCM City, Vietnam
}

Received 16 February 2020

Revised 23 March 2020; Accepted 28 May 2020

\begin{abstract}
Training teachers to meet the professional standards is one of the top missions prioritized by teacher training institutions. Nevertheless, how student-teachers' teaching competency is assessed is considered as one of the highest concerns by teacher trainers and educators. This study, therefore, aims at examining student teachers' perception of their teaching competency assessed by a framework for assessing student teachers' English teaching competency (FASTETC) in the TESOL methodology course at a Ho Chi Minh City-based university, Vietnam. The study involved 85 student teachers majoring in TESOL methodology in answering a self-evaluation questionnaire. The results indicated that the research participants realized they could meet the course outcomes and professional standards in terms of attitudes, knowledge and skills of English teaching methodology (ETM) and English language proficiency. Furthermore, student teachers were aware that their knowledge and skills of ETM outperformed their attitudes of ETM. Such preliminary results can encourage the use of a teaching competency framework for assessing and assuring the quality of student teachers' teaching competency in similar contexts.
\end{abstract}

Keywords: methodology, student teacher, teaching competency, teaching competency framework, TESOL

\section{Introduction}

Many scholars (e.g., Alqiawi \& Ezzeldin, 2015; Bhargava \& Pathy, 2011; Zeichner, 2010) have asserted that building teaching competency plays a pivotal role in improving the quality of teaching and learning. Zeichner (2010) states that teaching competency should be embedded into the framework for assessing and self-assessing teaching competency. Likewise, Bhargava and Pathy (2011) pinpoint that educators and teacher trainers should integrate the teaching competency framework into teaching and training in an attempt to assure the quality of teaching and learning and fulfill their roles in teaching and learning appropriately and effectively. In a similar vein, Alqiawi and Ezzeldin (2015) postulate that teaching competency framework can be used as criteria and standards for orienting and determining the identities of good teachers. Based on the importance of teaching competency as such, different teaching competency frameworks for teachers have been designed and developed in many educational contexts.

In the Vietnamese context, educating teachers of English as a foreign language (EFL) to meet the professional standards has been prioritized in recent years. Accordingly, Vietnam's Ministry of Education and Training (MOET) has issued different decrees, decisions 
and guidelines on quality standards of teaching competency. In terms of English language teaching, in particular, teaching competency framework for teachers introduced by MOET (MOET, 2014) which features five domains, namely knowledge of language, language learning, and curricular content; knowledge of language teaching; knowledge of language learners; ethics and values in teaching; and practice and content of language teaching. Such a framework provides teacher-training institutions with guidelines on the development of frameworks for assessing teachers and student teachers' teaching competency in a bid to assure the quality of teachers' teaching competency as well as to respond to social needs. Nevertheless, how such frameworks are evaluated is a big issue for many educational teacher-training institutions. As for the Faculty of English of a Ho Chi Minh City-based University, albeit a newly emergent institution in training EFL teachers, it has designed and developed a framework for assessing student teachers' English teaching competency (FASTETC) in order to assure the training outcomes. FASTETC has been employed as a quality standard for assessing EFL student teachers' teaching competency in the teacher teaching program; however, there is a lack of research on the use of FASTETC in these programs. Therefore, within its scope, this study only endeavors to examine student teachers' perception of their teaching competency assessed by FASTETC in the TESOL methodology (hereafter: FASTETCbased TESOL methodology) course at this University, and the research question to be addressed is:

What is student teachers' perception of their teaching competency after the FASTECTbased TESOL methodology course?

\section{Literature review}

Scholars (e.g., Barman \& Paramanik, 2019; Deakin, 2008; Hagger \& McIntyre, 2006; Koster \& Dengirnk, 2008; Rychen \& Salganik, 2003) have addressed the terms of competence and teaching competency in different aspects. Deakin (2008) describes competence as a complex combination of knowledge, skills, understanding, qualities, attitudes and passion which enable one to act effectively. In a wider sense, Rychen and Salganik (2003) define that teaching competency encompasses components of knowledge, practical skills, motivation, belief, qualities and emotion which empower teachers to perform their teaching tasks. Furthermore, teachers' teaching competency, as confirmed by Koster and Dengirnk (2008), helps them to meet perplexing demands and accomplish their teaching tasks professionally and appropriately in specific circumstances. Barman and Paramanik (2019) have pointed out that competence has several characteristics: (i) Competence can include one or multi-skills enabling one to maintain that competence; (ii) Competence links three components of attitude, knowledge and skill which are used to assess a particular act; (iii) Competence is visible; (iv) competence can be assessed. Nevertheless, teaching competency differs from teacher competence. As explained by Hagger and McIntyre (2006), the former refers to teachers' roles in classroom to perform the teaching tasks, while the latter, in a wider sense, refers to teachers' professional competence implying "a wider, systemic view of teacher professionalism, on multiple levels - the individual, school, community and professional networks" (Ibid., p.10; as cited by European Commission, 2013). Likewise, researchers (e.g., Feiman-Nemser, 2001; McDiarmid \& Clevenger-Bright, 2008) have confirmed that teaching competency encompasses three basic components, namely knowledge, skills and attitudes.

Among those three, firstly, Attitude refers to commitment, confidence, belief and respect in teaching, and it can be positive and negative. It is a connection between knowledge and skills which helps teachers to carry out teaching tasks to meet the common educational goals and maximize learners' learning competence(Council of Europe, 2008; Feiman-Nemser, 2008). Secondly, Knowledge 
refers to teachers' profound pedagogical and professional knowledge which can help them to teach effectively in different educational environments (e.g., McDiarmid \& CkevengerBright, 2008; Krauss et al., 2008; Shulman, 1987). In order to fulfill the teaching missions well, teachers need to have knowledge of syllabus, classroom management, pedagogy, educational theories and learner assessment (Darling-Hammond, 2006). Finally, Skill refers to the ability to teach flexibly to meet learners' learning needs (Hatano \& Oura, 2003; Vogt \& Rogalla, 2009). Teachers' teaching skills are demonstrated by curriculum design, classroom management, teaching strategy use and learner testing and assessment (Scheerens, Luyten, Steen \& Luyten-de Thouars, 2007). Moreover, teachers' teaching skills are skills of evaluating their teaching systematically on the basis of theories, research, professional experiences and evidence to improve teaching and learning quality (Hagger \& McIntyre, 2006). The three abovementioned components are three pillars of teaching competency which are closely interconnected and support one another. Within the scope of this paper, based on the training outcomes, student teachers' English teaching competency is expanded as the ability to teach effectively in specific situations, comprising attitude, knowledge, skill and English language proficiency which enable teachers to transfer knowledge to others and solve educational classroom-based problems appropriately and effectively.

The importance of teaching competency and teaching competency framework for teachers has been confirmed by many researchers. Verloop (1999) has stated there is an increasing demand for assessing teaching competency for quality assurance and recognition of the teaching profession. Similarly, Roelofs and Sander (2007) mention that teacher training institutions should focus on competence-based training for assessing teachers' teaching competency. In another aspect, European Commission (2013) pinpoints that teaching competency frameworks can bring various benefits such as helping to stimulate teachers' active engagement in their career development and assess teachers' teaching competency development. Furthermore, a teaching competency framework for teachers has different features: it is institutionalized and contextualized; it is designed based on underlying educational/teaching philosophy, and a negotiated consensus about teaching goals and learning outcomes; and it has key features of stability, durability and flexibility (European Commission, 2013).

A number of teaching competency frameworks for teachers have been found in the body of literature. Internationally, for example, British Council Continuing Professional Development (CPD) Framework for Teachers of English (British Council, 2011) aims at providing a guide for primary and secondary school teachers to self-evaluate their teaching knowledge and skills and develop their profession. It includes four stages of development (awareness, understanding, engagement, integration) and 12 professional practices (Planning lessons and courses; Understanding learners; Managing the lesson; Knowing the subject; Managing resources; Assessing learning; Integrating ICT; Taking responsibility for professional development; Using inclusive practices; Using multilingual approaches; Promoting 21st century skills; Understanding educational policies and practice). In 2013, EAQUALS Framework for Teacher self-assessment, Language Teacher Training and Development (EAQUALS, 2013) was developed in England in an attempt to give guiding principles and tools for the enhancement of quality in language teaching and learning. This framework features three key professional competencies (attitudes, knowledge and skills), three development phases, and five main areas of competencies (planning teaching and learning; teaching and supporting learning; assessment of learning; language, communication and culture; the teacher as professional). A similar framework named Cambridge English Teaching Framework (UCLES, 2015) has been developed, and it aims at indicating the main knowledge 
and skills needed for effective teaching at different teaching stages and in different circumstances. This framework encompasses five main categories (Learning and the Learner; Teaching, Learning and Assessment; Language Ability; Language Knowledge and Awareness; Professional Development and Values) with 36 framework components, and it has four stages of teacher competency: Foundation; Developing; Proficient; Expert. It is noticed that although all the three frameworks are from the same country, they have different purposes and components.

In Vietnam, some teaching competency frameworks have been found. In 2012, Duong, Pham and Thai built an Assessment Competence Framework for Pre-service and Inservice ELT Teachers. This framework includes five domains of competences (Competence in language assessment design and process; Competence in connecting language assessment to instruction; Competence in developing language assessment instruments; Competence in using measurement models and statistics; Competence in conducting research in language assessment). However, this framework focuses on competences for conducting effective language assessment. In 2016, Pham and Ta developed a Theoretical Framework for ESP Teacher Training which aims at providing prospective ESP teachers with skills and knowledge in ESP. It has two components: ESP methodology (ESP pedagogical competence) and ESP acquisition (Field-specific linguistic competence and multi-disciplinary subject knowledge). Bui, Nguyen, Dao and Hoan (2017) presented professional standards for Vietnamese teachers. They analyzed the core competencies of Singaporean teachers and did the analysis and evaluation for the Grad and in-service teacher competencies framework in Vietnam. These frameworks have been designed for developing teachers' teaching competence; however, they are only theoretical ones and not yet evaluated.

Within this study, FASTETC was based on the training outcomes of the TESOL methodology course and developed for assessing student teachers' English teaching competency in the course of TESOL methodology at a Ho Chi Minh City-based University. FASTETC was developed based on the steps of the ADDIE model (Analyse Design - Develop - Implement - Evaluate) (Branch, 2009), and it has nine components (Theories of Language Learning Teachers and Learners; Planning lessons; Learning Resources; Classroom management; teaching techniques; Testing and Evaluation; Educational Technology; Class Observation; English Language Proficiency) with 24 criteria which are employed for assessing student teachers' teaching competency within a five-point scale (Fail, Average, Fairly Good, Good and Outstanding). The nine components of this framework serve as a part of the theoretical framework of this study.

\section{Methodology}

\subsection{Research setting}

This quantitative study was conducted at a Ho Chi Minh City-based university in Vietnam which offers different training programs at different levels and has 25 faculties, institutes and centers. The Faculty of English Language has the English Language training program, which includes three sub-majors: English for translation and interpretation, English for Business, and TESOL methodology. Students of these three majors have to study the same courses within the three academic years, and they have to study discrete courses for their sub-majors. Students who study TESOL methodology should take courses of Teaching Methodology 1 (3 credits), Teaching Methodology 2 (3 credits), Classroom Language and Management (3 credits), Contrastive Linguistics and Language Teaching (3 credits). Student teachers learn the theories of ETM from Teaching Methodology 1, teaching techniques from Teaching Methodology 2, English language use and classroom management from Classroom Language and Management, and theories of contrastive linguistics in language teaching from Contrastive Linguistics and Language 
Teaching. The sequence of courses should be Teaching Methodology 1, Classroom Language and management, Teaching Methodology 2 (Appendix for the main contents of the mentioned courses), and Contrastive Linguistics and Language Teaching.

For the purpose of this study, the FASTETC was introduced and explained to student teachers at the beginning of the course of TESOL methodology. However, the teaching practice was conducted in the course of Teaching Methodology 2 which included 45 periods divided into nine sections. During this course, student teachers were required to learn lessons of teaching techniques and do class observations within the first five sections. Regarding class observations, student teachers watched five clips of teachers teaching English at different levels of education. They had to write class observation individually and then in groups while watching those clips. Within the rest four sections, students had to demonstrate their teaching skills in groups of four people twice. Each group taught a selfchosen 60-minute lesson (15 minutes/person). During teaching demonstration, other students played roles of learners and had to write class observation. At the end of each demonstration, both teacher trainer and student teachers gave feedback and comments on the teaching demonstration, and evaluation on teaching demonstration was carried out by both teacher trainer (80\%) and students (20\%).

\subsection{Research participants}

This study involved 85 student teachers in answering a questionnaire. They were conveniently sampled from three intact classes of student teachers who were majoring in TESOL methodology at a Ho Chi Minh Citybased university, Vietnam. As seen from Table 1, there were 18 males (21.2\%) and 67 females (78.8\%). Most of the research participants were aged $21-30(98.8 \%)$, and 74 out of 85 students $(87.1 \%)$ had learned English for more than 10 years. More than a half $(57.8 \%)$ opted for TESOL methodology because of passion, from family's career orientation $(31.8 \%)$ and others (10.6\%). Nearly $60 \%$ of student teachers had teaching experience at different positions (teaching assistant: $22.4 \%$; tutor: $28.2 \%$; full-time teacher: $7.15 \%$ ), and most of them (42/49) had taught English for less than 2 years. There were 23 student teachers $(27.1 \%)$ who had ever taken a course of TESOL methodology before.

Table 1. Research participants' background information

\begin{tabular}{|c|c|c|c|c|}
\hline \multirow{2}{*}{ No. } & & & \multicolumn{2}{|c|}{$\mathrm{n}=\mathbf{8 5}$} \\
\hline & & & $\mathbf{F}$ & $\%$ \\
\hline \multirow{2}{*}{1} & \multirow{2}{*}{ Gender } & Male & 18 & 21.2 \\
\hline & & Female & 67 & 78.8 \\
\hline \multirow{3}{*}{2} & \multirow{3}{*}{ Age } & Under 20 & 1 & 1.2 \\
\hline & & $21-30$ & 84 & 98.8 \\
\hline & & Over 30 & 0 & 0 \\
\hline \multirow{3}{*}{3} & \multirow{3}{*}{ English learning experience } & Under 5 years & 0 & 0 \\
\hline & & $5-10$ years & 11 & 12.9 \\
\hline & & Over 10 & 74 & 87.1 \\
\hline \multirow{3}{*}{4} & \multirow{3}{*}{$\begin{array}{l}\text { Reasons for studying TESOL } \\
\text { methodology }\end{array}$} & Passion & 49 & 57.8 \\
\hline & & Family's carrier orientation & 27 & 31.8 \\
\hline & & Others & 9 & 10.6 \\
\hline \multirow{4}{*}{5} & \multirow{4}{*}{ Experience of English teaching } & Teaching assistant & 19 & 22.4 \\
\hline & & Tutor & 24 & 28.2 \\
\hline & & Full time teacher & 6 & 7.1 \\
\hline & & Not yet & 36 & 42.2 \\
\hline
\end{tabular}




\begin{tabular}{|c|c|c|c|c|}
\hline \multirow{3}{*}{6} & \multirow{3}{*}{ Years of English teaching } & Under 1 year & 20 & 23.5 \\
\hline & & $1-2$ years & 22 & 25.9 \\
\hline & & Over 2 years & 7 & 8.2 \\
\hline \multirow{2}{*}{7} & Experience of previous study of the & Yes & 23 & 27.1 \\
\hline & TESOL methodology course & No & 62 & 72.9 \\
\hline
\end{tabular}

Note: n: sample; F: frequency; \%: percentage

3.3. Research instrument and procedures for data collection and analysis

A questionnaire designed from the theoretical framework was employed to collect data. It encompasses two parts: Part A asking for general background information; Part B including 73 items of perception of English teaching competency in terms of attitudes, knowledge, skills, and English language proficiency. The questionnaire used a five-point Likert scale from Very low to Very high. The total Cronbach's alpha of the questionnaire is .94 (73 items). The Cronbach's alpha of groups of attitudes, knowledge, skills, and English language proficiency are .92 (23 items), .92 (23 items), .94 (23 items), and .87 (4 items), respectively. This means that the reliability of the questionnaire is very high.

Regarding the data collection, the questionnaire had been piloted before the questionnaire was officially used in the main study. The questionnaire was administered with 123 student teachers at the end of Teaching Methodology 2 course. It took from 30-35 minutes to complete the questionnaire. Only 85 copies of questionnaire were returned. With respect to data analysis, the SPSS software was utilized to analyze data in terms of descriptive statistics (mean and standard deviation). The interpretation of mean scores is $1.00-1.80$ : Very low; 1.81 - 2.60: Low; 2.61 - 3.40: Moderate; 3.41 - 4.20: High; 4.21 - 5.00: Very high.

\section{Results and discussion}

\subsection{Results}

4.1.1 Student teachers' perception of their teaching competency after the FASTETCbased TESOL methodology course

As seen from Table 2, the mean score of research participants' teaching competency after the FASTETC-based TESOL methodology course is 3.84. Among four components of the teaching competency, the mean score of knowledge (Group $\mathrm{B}: \mathrm{M}=3.93$; $\mathrm{SD}=.43$ ) is the highest, followed by skills (Group C: $\mathrm{M}=3.81$; $\mathrm{SD}=.46)$ and English language proficiency (Group D: $\mathrm{M}=3.60$; $\mathrm{SD}=.67$ ). The lowest mean score is attitudes (Group A: $\mathrm{M}=3.14$; $\mathrm{SD}=.71)$. This can be interpreted that student teachers realized that their teaching competency was at a high level. Their knowledge, skills of ETM and English language proficiency were at a high level, while their attitudes towards ETM was at a moderate level.

Table 2. Student teachers' perception of teaching competency

\begin{tabular}{cccc}
\hline \multirow{2}{*}{ Group } & \multirow{2}{*}{ Components } & \multicolumn{2}{c}{$\mathbf{n}=\mathbf{8 5}$} \\
\cline { 3 - 4 } & Attitudes & 3.14 & SD \\
\hline $\mathrm{A}$ & Knowledge & 3.93 & .71 \\
\hline $\mathrm{B}$ & Skills & 3.81 & .43 \\
\hline $\mathrm{C}$ & English language proficiency & 3.60 & .46 \\
\hline $\mathrm{D}$ & Total & $\mathbf{3 . 8 0}$ & .67 \\
\hline & & $\mathbf{3 6}$ \\
\hline
\end{tabular}

Note: n: sample; M: mean; SD: standard deviation 
4.1.2. Components of student teachers' perception of teaching competency after the FASTETC-based TESOL methodology course

Regarding the student teachers' teaching competency in terms of attitudes, Table 3 shows that research participants perceived that their attitudes of theories of "language teachers" (Item 3: $\mathrm{M}=4.02 ; \mathrm{SD}=.53$ ), "common language teaching methods" (Item $4: \mathrm{M}=4.01 ; \mathrm{SD}=.66)$, "language learning" (Item 1: $\mathrm{M}=4.00 ; \mathrm{SD}=.61$ ), "language learners" (Item 2: $\mathrm{M}=3.62 ; \mathrm{SD}=.59$ ) were at a high level. Additionally, they believed that they could gain a high level of attitudes towards techniques for teaching English "vocabulary" (Item 5: $\mathrm{M}=3.56 ; \mathrm{SD}=.71$ ), "grammar" (Item 6: M $=3.56 ; \mathrm{SD}=.74$ ), "pronunciation" (Item 7: $\mathrm{M}=3.75 ; \mathrm{SD}=.55)$, "reading skill" (Item 8: $\mathrm{M}=3.76 ; \mathrm{SD}=.54)$, "how to assess learner' learning" (Item 20: M $=3.42 ; \mathrm{SD}=.87)$, "how to design a language test" (Item 21: $\mathrm{M}=3.54 ; \mathrm{SD}=.94)$, and "how to evaluate a teaching class" (Item 23: $\mathrm{M}=$
3.40; $\mathrm{SD}=.84)$.

Nonetheless, their attitudes towards techniques for teaching "listening skill" (Item 9: $\mathrm{M}=3.00 ; \mathrm{SD}=1.01$ ), "speaking" (Item 10: $\mathrm{M}=2.94 ; \mathrm{SD}=.52$ ), "writing skill” (Item 11: $\mathrm{M}=2.89$; $\mathrm{SD}=.64$ ), "how to design lesson plans" (Item 12: $\mathrm{M}=3.34$; $\mathrm{SD}=.61$ ), "how to design a teaching curriculum" (Item 22: $\mathrm{M}=2.99$; $\mathrm{SD}=.77$ ), "how to use teaching materials" (Item 14: $\mathrm{M}=2.98 ; \mathrm{SD}=.78$ ), "how to use teaching aids" (Item 15: $\mathrm{M}=3.02$; $\mathrm{SD}=.53$ ), "how to use educational technology in teaching" (Item 16: $\mathrm{M}=3.12$; $\mathrm{SD}=.89$ ), "how to manage the classroom" (Item 17: M $=3.06$; $\mathrm{SD}=.51)$, "how to solve classroombased problems" (Item 18: $\mathrm{M}=3.06$; $\mathrm{SD}=$ .96), "how to organize teaching activities" (Item 19: $\mathrm{M}=3.35 ; \mathrm{SD}=.86$ ), and "how to observe a teaching class" (Item 22: $\mathrm{M}=3.31$; $\mathrm{SD}=.88$ ) were at a moderate level. These findings can mean student teachers discerned that they had positive attitudes towards theories of ETM.

Table 3. Student teachers' perception of teaching competency in terms of attitudes

\begin{tabular}{|c|c|c|c|}
\hline \multirow{2}{*}{ No. } & \multirow{2}{*}{ I like learning... } & \multicolumn{2}{|c|}{$n=85$} \\
\hline & & $\mathbf{M}$ & SD \\
\hline 1 & theories of language learning. & 4.00 & .61 \\
\hline 2 & theories of language learners. & 3.62 & .59 \\
\hline 3 & theories of language teachers. & 4.02 & .53 \\
\hline 4 & theories of common language teaching methods. & 4.01 & .66 \\
\hline 5 & techniques for teaching English vocabulary. & 3.56 & .71 \\
\hline 6 & techniques for teaching English grammar. & 3.56 & .74 \\
\hline 7 & techniques for teaching English pronunciation. & 3.75 & .55 \\
\hline 8 & techniques for teaching English reading skill. & 3.76 & .54 \\
\hline 9 & techniques for teaching English listening skill. & 3.00 & .61 \\
\hline 10 & techniques for teaching English speaking skill. & 2.94 & .52 \\
\hline 11 & techniques for teaching English writing skill. & 2.89 & .64 \\
\hline 12 & how to design lesson plans. & 3.34 & .61 \\
\hline 13 & how to design a teaching curriculum. & 2.99 & .77 \\
\hline 14 & how to use teaching materials. & 2.98 & .78 \\
\hline 15 & how to use teaching aids. & 3.02 & .53 \\
\hline 16 & how to use educational technology in teaching. & 3.12 & .89 \\
\hline 17 & how to manage the classroom. & 3.06 & .51 \\
\hline 18 & how to solve classroom-based problems. & 3.06 & .96 \\
\hline 19 & how to organize teaching activities. & 3.35 & .86 \\
\hline 20 & how to assess learner' learning. & 3.42 & .87 \\
\hline 21 & how to design a language test. & 3.54 & .64 \\
\hline 22 & how to observe a teaching class. & 3.31 & .88 \\
\hline 23 & how to evaluate a teaching class. & 3.40 & .84 \\
\hline
\end{tabular}


As seen from Table 4, after the FASTETCbased TESOL methodology course, research participants thought that their knowledge of theories of "language learning" (Item 24: M $=3.93 ; \mathrm{SD}=.73$ ), "language learners" (Item $25: \mathrm{M}=3.89 ; \mathrm{SD}=.75)$, "language teachers" (Item 26: $\mathrm{M}=4.01 ; \mathrm{SD}=.62$ ) and "common language teaching methods" (Item 27: $\mathrm{M}=$ 4.04; $\mathrm{SD}=.62$ ) was at a high level. Likewise, they also gained knowledge of techniques for teaching English "vocabulary" (Item 28: $\mathrm{M}=$ 4.06; $\mathrm{SD}=.63$ ), "grammar" (Item 29: $\mathrm{M}=$ 4.12; $\mathrm{SD}=.64)$, "pronunciation" (Item 30: M $=3.98 ; \mathrm{SD}=.55$ ), "reading skill" (Item 31: M $=4.02 ; \mathrm{SD}=.67)$, "listening skill" (Item 32: $\mathrm{M}=3.96$; $\mathrm{SD}=.66$ ), "speaking skill" (Item 33: $\mathrm{M}=3.86 ; \mathrm{SD}=.67)$, and "writing skill" (Item 34: $\mathrm{M}=3.98 ; \mathrm{SD}=.70$ ) at a high level.

Regarding other areas of knowledge of ETM, they knew how to "design lesson plans"
(Item 35: $\mathrm{M}=3.93 ; \mathrm{SD}=.70)$, "design a teaching curriculum" (Item 36: M = 3.98; SD $=.69$ ), "use teaching materials" (Item 37: M $=3.99$; SD = .66), "use teaching aids" (Item 38: $\mathrm{M}=3.95$; $\mathrm{SD}=.59)$, "use educational technology in teaching" (Item 39: $\mathrm{M}=4.01$; $\mathrm{SD}=.58)$, "manage the classroom" (Item 40: $\mathrm{M}=3.95 ; \mathrm{SD}=.57)$, "solve classroom-based problems" (Item 41: $\mathrm{M}=3.95 ; \mathrm{SD}=.65$ ), "organize teaching activities" (Item 42: M $=3.92$; SD = .74), "assess learner' learning" (Item 43: $\mathrm{M}=3.96 ; \mathrm{SD}=.58$ ), "design a language test" (Item 44: $\mathrm{M}=3.54$; $\mathrm{SD}=$ .69), "observe a teaching class" (Item 45: M $=3.88 ; \mathrm{SD}=.64)$, and "evaluate a teaching class" (Item 46: $\mathrm{M}=3.82 ; \mathrm{SD}=.67$ ) at a high level. Such findings can indicate that student teachers believed they had profound knowledge of ETM.

Table 4. Student teachers' perception of teaching competency in terms of knowledge

\begin{tabular}{llcc}
\hline \multirow{2}{*}{ No. } & \multicolumn{1}{c}{ I have learned knowledge of... } & M & n=85 \\
\cline { 3 - 4 } & & 3.93 & .73 \\
\hline 24 & theories of language learning. & 3.89 & .75 \\
\hline 25 & theories of language learners. & 4.01 & .62 \\
\hline 26 & theories of language teachers. & 4.04 & .71 \\
\hline 27 & theories of common language teaching methods. & 4.06 & .64 \\
\hline 28 & techniques for teaching English vocabulary. & 4.12 & .64 \\
\hline 29 & techniques for teaching English grammar. & 3.98 & .63 \\
\hline 30 & techniques for teaching English pronunciation. & 4.02 & .67 \\
\hline 31 & techniques for teaching English reading skill. & 3.96 & .66 \\
\hline 32 & techniques for teaching English listening skill. & 3.86 & .67 \\
\hline 33 & techniques for teaching English speaking skill. & 3.98 & .70 \\
\hline 34 & techniques for teaching English writing skill. & 3.93 & .70 \\
\hline 35 & how to design lesson plans. & 3.98 & .69 \\
\hline 36 & how to design a teaching curriculum. & 3.99 & .66 \\
\hline 37 & how to use teaching materials. & 3.95 & .59 \\
\hline 38 & how to use teaching aids. & 4.01 & .58 \\
\hline 39 & how to use educational technology in teaching. & 3.95 & .57 \\
\hline 40 & how to manage the classroom. & 3.95 & .65 \\
\hline 41 & how to solve classroom-based problems. & 3.92 & .74 \\
\hline 42 & how to organize teaching activities. & 3.96 & .58 \\
\hline 43 & how to assess learner' learning. & 3.88 & .69 \\
\hline 44 & how to design a language test. & 3.85 & .64 \\
\hline 45 & how to observe a teaching class. & 3.82 & .67 \\
\hline 46 & how to evaluate a teaching class. & & \\
\hline & & & \\
\hline
\end{tabular}

Note: n: sample; M: mean; SD: standard deviation 
Similarly, results in Table 5 present that student teachers supposed they had skills applying theories of "language learning" (Item 47: $\mathrm{M}=3.95 ; \mathrm{SD}=.59$ ), "language learners" (Item 48: $\mathrm{M}=3.84 ; \mathrm{SD}=.59$ ), and "language teachers" (Item 49: $\mathrm{M}=3.79$; $\mathrm{SD}=.63)$ and "common language teaching methods" (Item 50: $\mathrm{M}=3.86$; $\mathrm{SD}=.62$ ) into their teaching at a high level. Regarding their skills of techniques for teaching English "vocabulary" (Item 51: M = 3.91; SD = .64), "grammar" (Item 52: M = 3.89; SD = .57), "pronunciation" (Item 53: $\mathrm{M}=3.85$; $\mathrm{SD}=$ .60 ), "reading skill" (item 54: $\mathrm{M}=3.91$; SD $=.66$ ), "listening skill" (Item 55: $\mathrm{M}=3.95$; $\mathrm{SD}=.61$ ), "speaking skill" (Item 56: $\mathrm{M}=$ 3.86 ; $\mathrm{SD}=.63$ ) and "writing skill" (Item 57: $\mathrm{M}=3.82$; $\mathrm{SD}=.65$ ), they gained such skills at a high level. They had skills of "designing lesson plans" (Item 58: $\mathrm{M}=3.82$; $\mathrm{SD}=.65$ ) and "designing a teaching curriculum" (Item 59: $\mathrm{M}=3.76$; $\mathrm{SD}=.75)$, "using teaching materials" (Item 60: $\mathrm{M}=3.76 ; \mathrm{SD}=.70$ ), "using teaching aids" (Item 61: $\mathrm{M}=3.85$; SD $=.62$ ) and "using educational technology in teaching" (Item 62: $\mathrm{M}=3.89 ; \mathrm{SD}=.61$ ) at a high level.

What is more, their skills of "managing the classroom" (Item 63: $\mathrm{M}=3.82 ; \mathrm{SD}=.67$ ), "solving classroom-based problems" (Item $64: \mathrm{M}=3.81 ; \mathrm{SD}=.66$ ), "organizing teaching activities" (Item 65: $\mathrm{M}=3.73$; $\mathrm{SD}=.73$ ), "assessing learner' learning" (Item 66: $\mathrm{M}=$ 3.88; SD = .62) and "designing a language test" (Item 67: $\mathrm{M}=3.73 ; \mathrm{SD}=.71$ ) were at a high level, too. For other skills of "observing a teaching class" (Item 68: $\mathrm{M}=3.68 ; \mathrm{SD}=$ .69) and "evaluating a teaching class" (Item 69: $\mathrm{M}=3.68 ; \mathrm{SD}=.67$ ), they believed they gained those skills at a high level.

Table 5. Student teachers' perception of teaching competency in terms of skills

\begin{tabular}{|c|c|c|c|}
\hline \multirow{2}{*}{ No. } & \multirow{2}{*}{ I have had skills of ... } & \multicolumn{2}{|c|}{$\mathrm{n}=\mathbf{8 5}$} \\
\hline & & M & SD \\
\hline 47 & applying theories of language learning into my teaching. & 3.95 & .59 \\
\hline 48 & applying theories of language learners into my teaching. & 3.84 & .59 \\
\hline 49 & applying theories of language teachers into my teaching. & 3.79 & .63 \\
\hline 50 & applying theories of common language teaching methods into my teaching. & 3.86 & .62 \\
\hline 51 & using techniques for teaching English vocabulary. & 3.91 & .64 \\
\hline 52 & using techniques for teaching English grammar. & 3.89 & .57 \\
\hline 53 & using techniques for teaching English pronunciation. & 3.85 & .60 \\
\hline 54 & using techniques for teaching English reading skill. & 3.91 & .66 \\
\hline 55 & using techniques for teaching English listening skill. & 3.95 & .61 \\
\hline 56 & using techniques for teaching English speaking skill. & 3.86 & .63 \\
\hline 57 & using techniques for teaching English writing skill. & 3.82 & .65 \\
\hline 58 & designing lesson plans. & 3.73 & .64 \\
\hline 59 & designing a teaching curriculum. & 3.76 & .75 \\
\hline 60 & using teaching materials. & 3.76 & .70 \\
\hline 61 & using teaching aids. & 3.85 & .62 \\
\hline 62 & using educational technology in teaching. & 3.89 & .61 \\
\hline 63 & managing the classroom. & 3.82 & .67 \\
\hline 64 & solving classroom-based problems. & 3.81 & .66 \\
\hline 65 & organizing teaching activities. & 3.73 & .73 \\
\hline 66 & assessing learner' learning. & 3.88 & .62 \\
\hline 67 & designing a language test. & 3.73 & .71 \\
\hline 68 & observing a teaching class. & 3.68 & .69 \\
\hline 69 & evaluating a teaching class. & 3.68 & .67 \\
\hline
\end{tabular}


With respect of English language proficiency, Table 6 reveals that after the FASTETC-based TESOL methodology course, student teachers self-reported that they had a high level of "listening skill" (Item
70: $\mathrm{M}=3.69 ; \mathrm{SD}=.72)$, "speaking skill" (Item 71: $\mathrm{M}=3.60 ; \mathrm{SD}=.77$ ), "reading skill" (Item 72: $\mathrm{M}=3.54 ; \mathrm{SD}=.82$ ), and "writing skill" (Item 73: $\mathrm{M}=3.62 ; \mathrm{SD}=.77$ ) to become teachers of English.

Table 6. Student teachers' perception of teaching competency in terms of English language proficiency

\begin{tabular}{cccc}
\hline \multirow{2}{*}{ No. } & I am competent in... & M & n=85 \\
\cline { 3 - 4 } & Listening skill to become a teacher of English. & 3.69 & .72 \\
\hline 70 & Speaking skill to become a teacher of English. & 3.60 & .77 \\
\hline 71 & Reading skill to become a teacher of English. & 3.54 & .82 \\
\hline 72 & Writing skill to become a teacher of English. & 3.62 & .77 \\
\hline 73 & Note: n: sample; M: mean; SD: standard deviation
\end{tabular}

\subsection{Discussion}

The study has uncovered some significant results which indicated that student teachers realized their teaching competency was at a high level after the FASTETC-based TESOL methodology course. This can be inferred that the employment of FASTETC in the course of TESOL methodology to assess student teachers' teaching competency could contribute to the development of their teaching competency. One of the possible explanations for this result is that student teachers may have recognized the FASTETC as a benchmark for their teaching competency development. This result is supported by Bhargava and Pathy (2011) who confirmed that teaching competency frameworks embedded into teaching and training can help to assure of the quality of teacher training, and it is also in alignment with Alqiawi and Ezzeldin's (2015) statement which confirmed that teaching competency can be used for quality assurance and identity of good teachers.

As regards the components of teaching competency, it was noticed that student teachers believed that their knowledge of ETM developed at the highest level, followed by skills of ETM and English language proficiency, and attitudes of ETM. It can be explained that student teachers could find it easier to gain knowledge and skills of ETM than other components of teaching competency. Remarkably, student teachers' attitudes of ETM developed at the lowest level in comparison with other components of ETM. It is possible that student teachers may believe that knowledge and skills of ETM could be more important than their attitudes of ETM. Another reason may be that student teachers' knowledge and skills of ETM could be the components of teaching competency that they had to learn and practice more than other components. Further explanation can be from the fact that $60 \%$ of research participants had teaching experiences and over $25 \%$ of research participants had ever learned a course of ETM before.

In respect of items in attitudes of ETM, student teachers indicated that their attitudes of theories of language learning, language teachers and common language teaching methods were at the highest level of development, while their attitudes of techniques for teaching English writing skill and speaking skill, how to use teaching materials and design a teaching curriculum were at the lowest level of development in comparison with other items. It seems that student teachers may prefer learning something easier to them. This can be one of the plausible reasons why their attitudes of ETM demonstrate that way. Such positive attitudes of ETM can help to acquire other components (knowledge and skills) of ETM. This finding corroborates with the idea of Council of Europe (2008) and Feiman-Nemser (2008) who have asserted that positive attitudes 
of language teaching can be a connection between knowledge and skills for teachers to accomplish their teaching tasks.

Within the items in knowledge of ETM, student teachers self-evaluated that they could gain knowledge of techniques for teaching vocabulary, grammar, and reading skill, theories of common language teaching approaches and language teachers, and using educational technology in teaching at a higher level of development than other items. It seems easy to understand that some items (item 12: theories of common language teaching approaches \& item 13: theories of language teachers) in attitudes of ETM which student teachers liked to learn were at a high level of development in the knowledge of ETM. However, their knowledge of techniques for teaching vocabulary, grammar, and reading skill and using educational technology may be closely relevant to themselves, so they could have gained more knowledge of those items than other ones. Furthermore, one of the plausible explanations for this can be that student teachers had positive attitudes of ETM, which possibly entails the profound of knowledge of ETM as confirmed by Council of Europe (2008) and Feiman-Nemser (2008). Consequently, student teachers were knowledgeable of ETM. This finding is in alignment with the statement made by DarlingHammond (2006) who indicates that teachers should possess pedagogical knowledge to do teaching missions well.

Nonetheless, the items in skills of ETM were at a relatively equal rate of development. This can be explained that student teachers had a chance to practice their teaching skills within the course of ETM development, and many of them had teaching experiences, so they could have focused more on skills of ETM than the other components of ETM. As discussed that the three components of teaching competency can influence one another (Council of Europe, 2008; Feiman-Nemser, 2008); therefore, when student teachers' knowledge of ETM was substantial enough, their skills of ETM could easily develop at a high level. They had skills of teaching learners effectively as confirmed by Hatano and Oura (2003) and Vogt and Rogalla (2009), those of curriculum design, classroom management, teaching strategy use and learner testing and assessment described by Scheerens et al. (2007).

Regarding student teachers' English language proficiency, they self-evaluated it at a high level, and they were proficient enough to become teachers of English; however, the level of development was relatively lower than knowledge and skills of ETM. This can be that it could take student teachers more time to develop their English language proficiency than other components of ETM, and they could pay more attention to knowledge and skills of ETM.

\section{Concluding remarks}

This study has indicated that student teachers perceived that the FASTETC-based TESOL methodology course could, to some extent, help them to achieve the stipulated learning outcomes. Such a positive result on student teachers' development of teaching competency can be a threshold for their later teaching competency development when they become in-service teachers. Moreover, student teachers realized that this FASTETCbased TESOL methodology course could help them to have positive attitudes of ETM and delve into knowledge and skills of EMT significantly.

In order to better the use of FASTETC in the course of TESOL methodology, the following recommendations can be considered. First of all, teacher trainers should train student teachers in detail about the FASTETC so that student teachers can understand what FASTETC is, how it works, and in what way it is relevant to the course outcomes. Moreover, teacher trainers should be consistent in assessing student teachers' teaching competency, basing on objective criteria. Secondly, lecturers who teach language skills should be informed about the FASTETC so that they can train their students in accordance with the assessment criteria of FASTETC in terms of English language proficiency. Likewise, students should pay more attention to improving their English language beforehand, so they will be able to avoid the English language difficulties in taking the course of ETM as well as to meet the learning outcomes. Thirdly, student teachers 
should look for part-time jobs relevant to English language teaching in order to gain knowledge and skills of ETM, which can facilitate their teaching competency during the ETM course.

Nevertheless, this study still bears some limitations. Firstly, the pure quantitative research was employed in this study, so a further study should involve a mixed-methods study in triangulating the data as well as validating the findings. Secondly, a survey was conducted to gather research participants' perception of their teaching competency; hence, there should be an experiment with pre-test and post-test to measure student teachers' teaching competency for the future study so that the effectiveness of FASTETC can be further confirmed. Last but not least, this study used the FASTETC in a TESOL methodology course in which student teachers did not have much time to practice their teaching, so the FASTETC should be applied in the course of Teaching Practice in which student teachers will have more chances to practice and demonstrate their teaching.

\section{References}

Alqiawi, D., \& Ezzeldin, S. (2015). A Suggested Model for Developing and Assessing Competence of Prospective Teachers in Faculties of Education. World Journal of Education, 5(6), 65-73.

Barman, P., \& Paramanik, N. (2019). Status of the Teacher Competency among the B.Ed, Trainee Teachers: An Analytical Study. International Journal of Research in Social Sciences, 9(2), 477-488.

Bhargava, A., \& Pathy, M. (2011). Perceptions of student teachers about teaching competencies. American Educational Journal of Contemporary Research, 1(1), 77-81.

Branch, R. M. (2009). Instructional Design: The ADDIE Approach. New York: Springer.

Bui, M. D., Nguyen, N. T, Dao, T. V. A., \& Hoan, T. K. H. (2017). In the development of professional standards for Vietnamese teachers: Studies on Singapore's experience. International Journal of Educational Science and Research (IJESR), 7(2), 149-154.

Council of Europe (2008). White Paper of Intercultural Dialogue: Living together as equals in Dignity. Strasbourg: Council of Europe.

Çakır, A., \& Güngör, M. N. (2017). Pre-service teachers' evaluations of practices in teaching English to young learners in terms of 21 st century teacher qualifications. Journal of Language and Linguistic Studies, 13(1), 244-259.

Darling-Hammond, L. (2006). Constructing 21st century teacher education. Journal of Teacher Education, 57(3), 300-314.

Deakin, C. R. (2008). Pedagogy for citizenship. In F. Oser \& W. Veugelers (Eds.), Getting involved: Global citizenship development and sources of moral values (pp.31-55). Rotterdam: Sense Publishers.

Duong, T. M., Pham, T. T. H., \& Thai, H. L. T. (2012). Building an Assessment Competence Framework for Pre-service and In-service ELT Teachers in Vietnam. Paper presented at TESOLCONFERENCE: SEAMEO Vietnam.

European Commission (2013). Supporting teacher competence development for better learning outcomes. Brussels, Belgium: European Commission.

Feiman-Nemser, S. (2008). Teacher Learning. How do Teachers learn to teach? In Marylyn CochranSmith, Sharon Feiman-Nemser, D. John McIntyre (Eds.), Handbook of research on Teacher Education, Enduring Questions in Changing Contexts. New York/Abingdon: Routledge/ Taylor \& Francis.

Hagger, H., \& McIntyre, D. J. (2006). Learning teaching from teachers. Realizing the potential of school-based teacher education. Maidenhead: Open University Press.

Hatano, G, \& Oura, Y. (2003). Commentary: reconceptualising school learning using insight from expertise research. Educational Researcher, 32(8), 26-29.

Gardner, R. (1985). Social psychology and second language learning: The role of attitudes and motivation. London: Edward Arnold Publishers.

Koster, B., \& Dengerink, J. J. (2008). Professional standards for teacher educators: how to deal with complexity, ownership and function, Experiences from the Netherlands. European Journal of Teacher Education, 31(2), 135-149.

Krauss, S., Brunner, M., Kunter, M., Baumert, J., Blum, W., Neubrand, M., \& Jordan, A. (2008). Pedagogical Content Knowledge and Content Knowledge of Secondary Mathematics Teachers. Journal of Educational Psychology, 100(3), 716-725.

Masgoret, A., \& Gardner, R. (2003). Attitudes, motivation, and second language learning: A metaanalysis of studies conducted by Gardner and associates. Language Learning, 53, 123-163.

McDiarmid, W., \& Clevenger-Bright, M. (2008). Rethinking Teacher Capacity. In Marylyn CochranSmith, Sharon Feiman-Nemser, D. John 
McIntyre (Eds.), Handbook of Research on Teacher Education, Enduring questions in changing contexts. New York/Abingdon: Routledge/Taylor \& Francis.

Mishra, P., \& Koehler, M. J. (2006). Technological Pedagogical Content Knowledge: A Framework for Teacher Knowledge. Teachers College Record, 108, 1017-1054.

Pham, H. A., \& Ta, T. B. (2016). Developing a Theoretical Framework for ESP Teacher Training in Vietnam. The ESP Journal, 12(1), 66-84.

Roelofs, E., \& Sander, P. (2007). Towards a framework for assessing teacher competence. European Journal of Vocational Training, 40, 123-139.

Rychen, D. S., \& Salganik, L. H. (2003). Key Competencies for a successful life and a wellfunctioning society. Göttingen: Hogrefe \& Huber.

Scheerens, J., Luyten, J., Steen, R., \& Luyten-de Thouars, Y. (2007). Review and metaanalyses of school and teaching effectiveness. Enschede, The Netherlands: University of Twente, Department of Educational Organisation and Management.

Shulman, L. (1987). Knowledge and Teaching: foundations of the new reform. Harvard Educational Review, 57(1), 1-22.
Süral, S. (2019). An Examination of Pre-Service Teachers' Competencies in Lesson Planning. Journal of Education and Training Studies, 7(3), $1-13$.

Tremblay, P., \& Gardner, R. (1995). Expanding the motivation construct in language learning. Modern Language Journal, 79, 505-518.

Verloop, N. D. L. (1999). De lerar: Reviewstudie uitgevoerd in opdracht van PROO. Den Haag: NWO/PROO.

Vietnam's Ministry of Education and training (MOET) (2014). Official Dispatch No. 792/ BGDÐTNGCBQLGD, dated February 25th, 2014, on English Teacher Competency Framework. Hanoi: Ministry of Education and Training.

Vogt, F., \& Rogalla, M. (2009). Developing Adaptive Teaching Competency through coaching. Teaching and Teacher Education, 25(8), 1051-1060.

Zeichner. K. (2010). Preparing globally competent teachers: A U.S. perspective'. 2010 colloquium on the internationalization of teacher education. NAFSA: Association of International Educators. University of Washington, Seattle.

\title{
NHẬN THỨC CỦA GIÁO SINH VỀ NĂNG LỰC GIẢNG DẠYY ĐƯợC ĐÁNH GIÁ THEO KHUNG ĐÁNH GIÁ NĂNG LỰC GIẢNG DẠY TIẾNG ANH
}

\author{
Trần Quốc Thảo \\ Đại học Công Nghệ Tp. Hồ Chí Minh (HUTECH) \\ 475 A Điện Biên Phủ, Phwờng 25, Bình Thạnh, Hồ Chí Minh
}

Tóm tắt: Đào tạo giáo viên nhằm đáp ứng chuẩn nghề nghiệp là một trong những ưu tiên hàng đầu được các cơ sở đào tạo giáo viên đặt ra. Tuy nhiên, việc đánh giá năng lực giảng dạy của giáo sinh như thế nào được các nhà đào tạo giáo viên và giáo dục xem là một trong những mối quan tâm lớn. Do đó, nghiên cứu này nhằm tìm hiểu nhận thức của giáo sinh về năng lực giảng dạy (NLGD) của họ được đánh giá theo khung đánh giá NLGD thông qua khóa học Phương pháp giảng dạy tiếng Anh (PPGD) tại một trường đại học ở Thành phố Hồ Chí Minh. Tham gia trả lời bảng câu hỏi là 85 giáo sinh chuyên ngành PPGD tiếng Anh. Kết quả cho thấy giáo sinh cho rằng họ có thể đáp ứng chuẩn đầu ra của khóa học và chuẩn nghề nghiệp về thái độ, kiến thức, kỹ năng giảng dạy tiếng Anh và kỹ năng ngôn ngữ Anh. Ngoài ra, giáo sinh còn nhận thấy kiến thức và kỹ năng giảng dạy của họ phát triển cao hơn so với thái độ về PPGD tiếng Anh. Những kết quả đạt được ban đầu này có thể giúp cho việc phát triển và sử dụng khung đánh giá NLGD để đánh giá và đảm bảo chất lượng NLGD của giáo sinh ở các cơ sở đào tạo giáo viên tương tự.

Từ khóa: giáo sinh; khung đánh giá năng lực giảng dạy; năng lực giảng dạy; phương pháp giảng dạy; tiếng Anh 


\section{APPENDIX}

THE MAIN CONTENTS OF TEACHING METHODOLOGY 1, CLASSROOM LANGUAGE AND MANAGEMENT \& TEACHING METHODOLOGY 2

\begin{tabular}{|c|c|}
\hline \multicolumn{2}{|c|}{ TEACHING METHODOLOGY 1} \\
\hline Section 1 & The changing world of English \\
\hline Section 2 & Describing language \\
\hline Section 3 & Background issues in language learning \\
\hline Section 4 & Popular methodology \\
\hline Section 5 & Describing learners and teachers \\
\hline Section 6 & Describing learning contexts \\
\hline Section 7 & Educational technology and other teaching resources \\
\hline \multirow{2}{*}{ Section 8} & Teaching grammar \\
\hline & Teaching vocabulary \\
\hline Section 9 & Teaching pronunciation \\
\hline \multicolumn{2}{|c|}{ CLASSROOM LANGUAGE AND MANAGEMENT } \\
\hline Section 1 & The classroom \\
\hline Section 2 & The teacher \\
\hline Section 3 & The learners \\
\hline Section 4 & Key teacher interventions \\
\hline Section 5 & Facilitating interactions \\
\hline Section 6 & Establishing and maintaining appropriate behaviour \\
\hline Section 7 & The lessons \\
\hline Section 8 & Practice \\
\hline Section 9 & Practice \\
\hline \multicolumn{2}{|c|}{ TEACHING METHODOLOGY 2} \\
\hline Section 1 & Teaching language skills \\
\hline \multirow{2}{*}{ Section 2} & How to teach reading \\
\hline & How to teach writing \\
\hline \multirow{2}{*}{ Section 3} & How to teach speaking \\
\hline & How to teach listening \\
\hline Section 4 & Planning Lessons \\
\hline Section 5 & Testing and evaluation \\
\hline Section 6 & Teaching practice \\
\hline Section 7 & Teaching practice \\
\hline Section 8 & Teaching practice \\
\hline Section 9 & Teaching practice \\
\hline
\end{tabular}

